Global Sustainability

cambridge.org/sus

\section{Research Article}

Cite this article: Martinez LF (2019). Legal regime sustainability in outer space: theory and practice. Global Sustainability 2, e26, 1-6. https://doi.org/10.1017/sus.2019.21

Received: 9 May 2019

Revised: 31 October 2019

Accepted: 1 November 2019

Keywords:

UNCOPUOS; treaties; customary law;

sustainability; LTS Guidelines

Author for correspondence:

Larry F. Martinez, E-mail: larry.martinez@ csulb.edu

\title{
Legal regime sustainability in outer space: theory and practice
}

Larry F. Martinez (D)

California State University, Long Beach, USA

\section{Non-technical abstract}

Sustainable access to outer space is increasingly threatened by growing orbital clouds of satellites and debris. A boom in competitively priced commercial rocket launches has lowered prices, prompting satellite operators to begin deploying thousands of satellites. Six decades ago, 'hard law' international treaties established governance for outer space designed for the few governmental space programmes. Today, non-governmental commercial entities are operating under voluntary 'soft law' rules of the road that expose the deficiencies of the original treaties to empower regulatory supervision of the expanding commercial orbital presence. This paper suggests how a 'sustainable' system of governance, required for sustainable space access and exploration, may be promoted by increasing the costs of non-compliance.

\section{Technical abstract}

This article identifies a 'double sustainability' legal challenge where the sustainability (laws of physics) of outer space access is increasingly dependent on the sustainability (laws of nations) of the legal regime. Williamson's transaction cost theory explains the shift to 'soft' non-binding agreements that reduce entities' exposure to mandatory regulatory costs of compliance, but which at the same time threaten to undermine the legitimacy of the 'hard' law legal regime by non-complying practices of governmental and commercial entities. In 2019, the UN Committee on Peaceful Uses of Outer Space (UNCOPUOS) adopted a series of non-binding guidelines designed to ensure the long-term sustainability of outer space ('LTS Guidelines'). While the LTS Guidelines represent a consensus approval by the 70 members of the UNCOPUOS, their non-binding 'soft law' status presents challenges for compliance and enforcement. A possible solution is to establish a legal nexus between 'soft' law agreements and 'hard' treaty law that applies to all entities. This article explores whether the LTS Guidelines could evolve into binding legal norms as part of customary international law (CIL) by using national space legislation as evidence of state recognition of international legal norms regarding sustainable access and use of outer space. In other words, sustainable outer space access may require a sustainable outer space legal regime resting on both 'hard' and 'soft' legal instruments.

\section{Social media summary}

Technology sector billionaires are already launching and deploying constellations of thousands of micro-satellites to provide internet connectivity to both rural and urban regions around the globe. Concern about long-term sustainability of access to outer space amid clouds of space debris has resulted in formulations of voluntary UN guidelines to head off potentially cataclysmic orbital collisions producing ever more debris. The problem is that voluntary guidelines lack enforcement mechanisms, leading to the inevitable 'free rider' seduction to cheat. This article analyses how compliance with such guidelines may be pushed at the national level through state-enforced legislation and regulations. In this way, the UN's voluntary guidelines for de-orbiting micro-satellites before they become space debris gain binding regulatory muscle.

\section{Introduction}

(c) The Author(s) 2019. This is an Open Access Creative Commons Attribution licence (http:// creativecommons.org/licenses/by/4.0/), which permits unrestricted re-use, distribution, and reproduction in any medium, provided the original work is properly cited.

\section{CAMBRIDGE} UNIVERSITY PRESS
By the second decade of the 21st century, access to outer space had become, in the oft-quoted words of Ambassador Gregory L. Schulte, Deputy Assistant Secretary for the U.S. Department of Defense, 'congested, contested, and competitive' (Space Watch, 2011). Schulte's prescient 2011 observation was confirmed again on 27 March 2019, as India became the fourth country (after China, Russia and the United States) to demonstrate its possession of an anti-satellite capability when its Shakti system successfully destroyed an orbiting Indian satellite, thereby creating a large cloud of orbital debris. NASA Administrator Jim Bridenstine testified to the U.S. Congress about the Shakti test's consequences in a hearing held on 27 March 2019: 
NASA Administrator Jim Bridenstine touched on testing that creates space debris in a U.S. House of Representatives hearing on NASA's proposed budget on March 27. "Debris ends up being there for a long time. If we wreck space, we're not getting it back," Bridenstine said. "And it's also important to note that creating debris fields intentionally is wrong ... because some people like to test anti-satellite capabilities intentionally and create orbital debris fields that we today are still dealing with. And those same countries come to us for space situational awareness because of the debris field that they themselves created. "And that's being provided by the American taxpayer, not just to them, but to the entire world for free," he added. "The entire world (has to) step up and say, 'If you're going to do this, you're going to pay a consequence.' And right now, the consequence is not being paid."(Salazar, 2019)

As the Shakti debris cloud demonstrates, an increasingly intensive use of outer space by a growing diversity of governmental and commercial entities has raised global concern for the challenges posed not only by space debris, but also spectrum interference (i.e. 'jamming'), and space traffic management for the long-term sustainability of the open access regime stipulated by the 1967 Outer Space Treaty (OST) and later agreements (UNOOSA, 1967, 2019). This growing concern resulted in the 2010 decision by the United Nations Committee for the Peaceful Uses of Outer Space (UNCOPUOS) to form a Working Group on Long Term Sustainability (LTS) of Outer Space Activities, assigning it the task of formulating voluntary non-binding guidelines focusing on sustainable space utilization, space debris and space operations, space weather, and regulatory regimes (Martinez, 2018). At its June 2016 meeting, the plenary UNCOPUOS approved 12 of the proposed guidelines, while several remained on the UNCOPUOS agenda lacking the required consensus among the organization's 70 member states. Three years later at the June 2019 meeting, the UNCOPUOS formalized their acceptance of the 12 LTS Guidelines and authorized future work of the LTS Working Group. Although the LTS Guidelines are non-binding, their adoption by the UNCOPUOS and consideration by the UN General Assembly's 4th Committee, are evidence of a growing expectation at the highest levels of international policymaking that the LTS Guidelines could ensure that the evolving international legal regime for outer space includes enforceable 'rules of the road' to promote long-term sustainable access and use (Martinez, 2018).

\section{Legal regime 'sustainability': higher transaction costs for non-compliance}

This paper contends that ensuring the long-term sustainability of outer space as an open and accessible global commons realm may depend paradoxically on the 'sustainability' of the legal regime designed for its governance. It is a 'paradox' when one considers the two diverse realms; one a physical realm subject to the laws of physics and chemistry, that is actually governed by a 'virtual' realm operating according to the laws enforced by human beings. While legal ambiguity may create opportunities for diplomatic compromises, the orbital laws of space debris physics are unambiguous, as underlined by destruction of the U.S. Iridium satellite through a collision with the Russian Kosmos 2511 satellite in 2009 (Martinez, 2011). This paper argues that the 'sustainability' of the evolving legal regime for outer space is primarily determined by the degree to which entities comply with the regime's rules and regulatory actions, even if they are ostensibly 'voluntary' or 'nonbinding'. The challenge to the sustainability of the outer space legal regime is seen in the shift to non-binding 'soft' law arrangements as outer space is accessed increasingly by nongovernmental, commercial entities. However, the Shakti incident shows that governmental entities are likewise able to ignore voluntary guidelines with little or nothing 'paid' as a consequence, as pointed out by the NASA Administrator. In other words, 'voluntary' guidelines pose minimal 'transaction' costs for noncomplying entities; more 'binding' guidelines would exact a higher transaction cost as non-compliance violates higher ranked legal norms.

This paper finds that Nobel laureate Oliver Williamson's transaction cost theory provides a basis for measuring the legal sustainability of the regime needed to ensure 'real world' sustainable access by whether entities perceive non-compliance as exacting a higher transaction cost, often described as 'political' costs (Williamson, 1996). Williamson's transaction cost theory posits that by raising the political, and ultimately, legal costs of noncompliance, the existing 'tragedy of the commons' may be minimized within a 'tweaked' legal framework that shifts 'soft law' voluntary guidelines into categories of 'hard law' norms, such as those defined in the International Court of Justice Statute, i.e. general principles and customary international law (Hardin, 1968).

Compliance at the beginning of the space age over 60 years ago was comparatively straightforward as only two or three countries engaged in space exploration (Soviet Union, United States, China, and the future European Space Agency), all parties to existing treaties. As governmental entities, all were under direct supervision and funding control by state regulators. The legal status of non-governmental entities was an early disagreement between the Soviet Union and the United States during the drafting of the OST. Compromise wording was found by placing such nongovernmental, i.e. commercial, entities under the direct supervision of the authorizing state, usually the launching state (OST, Article VI). In contrast, by the end of the second decade of the 21 st century, a rapidly expanding commercial space launch market was lowering the costs of access to orbit, resulting in planned deployments of thousands of miniaturized 'cubesats' into earth's orbital regions by a multitude of diverse governmental and commercial entities. Combined with a market imperative to ensure competitiveness by reducing regulatory overheads, the once tight regulatory oversight by governments was loosening. Outer space, in essence, risks exemplifying another global commons realm such as the oceans and atmosphere whose open access regimes reveal the 'tragedy' of non-sustainability through noncompliance. Non-compliance was evident in India's March 2019 deliberate destruction of its Shakti satellite despite India's participation in on-going efforts such as the LTS Guidelines to curb space debris. With the compliance-sustainability problem in mind, this paper suggests a theoretical approach to re-establish a binding obligation on all entities accessing outer space to incentivize their legal compliance whether or not such entities are parties to existing international legal agreements and guidelines. In other words, what might be the next step(s) towards establishing a stickier regulatory grip for the voluntary LTS Guidelines?

\section{Space: 'congested, contested, and competitive'}

The growing consensus about the increasingly 'congested, contested, and competitive' nature of outer space access set the leitmotiv for the June 2018 commemoration in Vienna of the five decades since entry into force of the United Nations' Outer Space Treaty (OST), considered the 'constitution' for the outer space legal regime. While the 50-year OST commemoration 
celebrated an historical milestone, the 2018 Vienna meeting posed very large questions about the outer space realm's legal future over the coming decades in the face of mounting sustainability challenges such as space debris. While a comprehensive substantive analysis (i.e. legal practice) is beyond the scope of this paper, a focus on the Long-Term Sustainability (LTS) Guidelines adopted in 2016 and under consideration by UNCOPUOS in 2017-19 will provide particularly prescient (i.e. theoretical) clues about the direction outer space regime evolution will take.

All forms of governance operate upon and react to factors exogenous and endogenous to the regime. National governments must contend with foreign threats and opportunities as they simultaneously attempt to achieve internal goals amidst competing supports and demands posed by domestic political groups and processes. International regimes likewise are required to manage external and internal pressures necessitating a range of responses. Thus, the June 2018 61st session of UNCOPUOS was augmented by a Unispace +50 commemoration and a High Level Forum that focused on the space regime's contribution to achieving the UN's Sustainable Development Goals (SDGs) for earth-bound populations, an exogenous demand on the space regime. In contrast, the endogenous issue of the sustainability of outer space itself has become the key driving force behind outer space regime evolution towards a greater reliance on either binding or non-binding instruments (UNOOSA, 2019).

In this way, the LTS Guidelines function as the proverbial 'canary in the coal mine' signalling a most remarkable twist in regime evolution. Do the LTS Guidelines indicate an awareness of the part of sovereign states at the highest levels of international policymaking of the sustainability challenges facing outer space exploration, and in the process bring about a nascent but growing willingness to adopt voluntary international guidelines as nationally binding policies and regulations? Will these, in turn, form the basis for what could eventually become customary norms of international law addressing practices that compromise sustainable access and use of the outer space environment? In short, will the LTS 'soft law' Guidelines evolve to become more like 'hard law' instruments applicable to all entities conducing space activities?

\subsection{Hard and soft law: legal sustainability and the problem of enforcing compliance}

One of the most fascinating, if also not its most challenging aspects a legal scholar or practitioner encounters in an analysis of international law is the aspect concerning its central contradiction: Where and under what circumstances will a sovereign state voluntarily limit its own sovereignty by acceding to a treaty or joining an international organization? Thousands of 'hard law' treaties, agreements, and their implementation into intergovernmental organizations would seem to affirm that sovereign states do indeed take such steps. Especially when one considers global commons such as Antarctica, the high seas and deep seabed, ionosphere, electromagnetic spectrum and Earth's climate, states have assembled legal regimes in which members commit to comply with 'hard law' regime rules they consider binding on the permissible range of their own sovereign prerogatives. At the same time, an accelerating process of globalization has intermeshed states, societies and economies into globe-spanning networks of markets, transport and finance whose pace of change seems to overwhelm cumbersome traditional 'hard law' processes. Out of necessity, states, governmental and non-governmental entities increasingly seek international 'soft law' regulatory accommodations usually promulgated as non-binding 'rules of the road'. In some cases, these enjoy widespread compliance due to the 'selfenforcing' characteristics of the commons itself, such as the electromagnetic spectrum. For example, radio frequency 'jamming' negatively affects all users including the jammer, creating a selfenforcing regime (Martinez, 1985). Is the same true for space debris? In other words, do concerns on the part of sovereign states for sustainability of the outer space environment similarly 'selfenforce' non-binding rules of the road?

International law regulating outer space as a region for human use must contend with the fact that space is accessible only through technology. Thus, more than for any other 'commons' region, governance of outer space must develop rules that are technological in nature, and whose legitimacy must constantly adapt to dynamically evolving technological capabilities exercised by a growing range of governmental, civilian and commercial entities in their space activities. For example, rules designed to prevent biological contamination of planets and other space objects were examined as commercial entity SpaceX in February 2018 launched a Tesla automobile into a heliocentric orbit that crossed through the Martian orbital region some months later (Malik, 2018). The launch licence issued by the United States government did not require the extensive decontamination required by rules applying to space vehicles operating in the vicinity of biologically sensitive space objects, such as Mars, as stipulated by the Committee on Space Research rules to prevent biological contamination (COSPAR, 2006).

Does the non-binding nature of 'soft' law inevitably invite non-compliance? The record shows that even compliance with 'hard law' space treaties is problematical, especially with rules focusing on ensuring sustainable access and use of global commons (Hardin, 1968). For example, space debris in the form of 'dead' satellites drifting in the crowded sections of the geostationary orbital region pose collision threats with operating satellites. The UN's International Telecommunication Union (ITU) promulgated decades ago specific 'hard law' Radio Regulations requiring satellite operators to boost their soon-to-die satellites from the geostationary orbit (GSO) into higher 'graveyard' orbits (ITU, 2010). However, by one estimate, only $30 \%$ of GSO satellite operators by 2005 were complying with the ITU Radio Regulations. However, there is evidence that more recently decommissioned GSO satellites are increasingly likely to be boosted into the graveyard orbit due to increased scrutiny in the face of more frequent space debris incidents, such as the 2009 Iridium satellite collision with Kosmos 2251 (Wikipedia, 2009). Clearly, space debris is 'enforcing' compliance in unambiguous ways.

\subsubsection{The desire for legal certainty: enforcement}

Enforcement, then, would appear to be the key differentiator regarding compliance between non-binding 'soft law' arrangements and 'hard law' treaty regimes. Treaty 'hard' law specifies legal obligations to comply and in cases of disputes or noncompliance, parties are required to engage legal remedies that usually include arbitration or adjudication of disputes. These dispute settlement mechanisms are often completely missing from 'soft' law voluntary agreements. Nonetheless, commercial space entities may face enforcement of international legal obligations whether 'soft' or 'hard' as required by the governmental entity supervising their activities under the OST's Article VI, usually in the form of a government-issued launch licence or permit to use radio spectrum channels. Investors and insurance companies 
will carefully examine such licensing and regulatory certifications before exposing themselves to additional potential risk posed by their financial and legal relationship with a commercial operator. The LTS Guidelines adopted and pending by COPUOS illustrate the expanding realm of legal limbo posed by intensifying use of outer space by an increasingly diverse range of commercial entities, many of which are operating under a likewise increasingly diverse range of Article VI-inspired licensing and supervisorial arrangements by launching state governments. These pose a clear invitation to divergent practices, accidents, disputes and lawsuits. Just as the 1960 s-70s 'hard' law treaties brought a large measure of legal certainty to outer space exploration, the LTS Guidelines are indicative of the desire by many governmental and commercial entities for a similar legal certainty in a rapidly evolving space marketplace. A first step toward greater legal certainty would be to examine whether voluntary 'rules of the road' for commercial use of outer space can evolve to exert a stronger requirement for compliance and possibly even adjudication and enforcement if found by an international court to constitute a 'general practice accepted as law' (United Nations, 2018).

\subsubsection{Customary International Law (CIL): binding on all states}

Perhaps the most effective way to address the problem of soft law non-compliance would be to establish through adjudication that such voluntary agreements have evolved to constitute customary international law (CIL). CIL is defined in the ICJ Statute as 'international custom, as evidence of a general practice accepted as law' (United Nations, 2018). CIL is specifically identified as one of the sources of international law that judges on the International Court Justice (ICJ) may use for forming a decision. Once recognized by the ICJ or other court, a 'general practice (of states) accepted as law' may operate as a 'hard' source of international law creating a binding obligation to comply with 'soft' law guidelines even for states and entities seeking to avoid making themselves subject to such legal instruments. With regard to outer space sustainability, while many 'soft law' regimes focus mainly on Earthbound commons regions, outer space presents a unique set of off-planet challenges that highlight the sovereignty contradiction inherent in hard law treaty compliance, the underlying theme of this paper. In other words, can states as sovereign entities be compelled to comply with international legal treaties they did not sign? To answer, we must briefly examine international law itself.

\subsection{International law: the hard truth about soft law}

According to the International Court of Justice (ICJ) Statute, there are four sources of international law the judges may use in their decision-making process: (1) treaties, (2) customary law, (3) general principles and (4) the writings of international legal scholars and other court decisions.

Article 38:

1. The Court, whose function is to decide in accordance with international law such disputes as are submitted to it, shall apply:

A. international conventions, whether general or particular, establishing rules expressly recognized by the contesting states;

B. international custom, as evidence of a general practice accepted as law; C. the general principles of law recognized by civilized nations;

D. subject to the provisions of Article 59, judicial decisions and the teachings of the most highly qualified publicists of the various nations, as subsidiary means for the determination of rules of law. (United Nations, 2018)
To varying degrees as interpreted by ICJ judges in their decisionmaking process, the four sources constitute binding, i.e. 'hard' international law. But a reliance on 'hard' law to settle disputes in an increasingly inter-connected 21st century world economy and globe-spanning technologies has been found lacking. The need for a more nimble and flexible set of international 'rules of the road' has spawned a wide assortment of 'soft' non-binding legal arrangements established through a variety of means including exchanges of letters, legal memoranda and commercial contracts. These are increasingly prevalent as state and non-state entities find that 'soft law' guidelines that coalesce around major functional areas such as the internet, weapons of mass destruction (WMD) proliferation, or outer space exploration, are useful for protecting very valuable proprietary commercial information and cybersecurity vulnerabilities. Again, the chief problem is leaky enforcement mechanisms to incentivize compliance, especially among non-signers. Is it possible to instil a degree of 'hardness' to 'soft' agreements?

The LTS Guidelines are where the legal rubber meets the technological road, transactional turn signals towards a major change in direction for the outer space legal regime. The longstanding 'hard law' OST stipulations that exploration and the use of outer space must ensure its 'benefit for all mankind' are, through the LTS Guidelines, being re-calibrated for sustainable use of outer space itself and its legal regime, politically feasible only through 'soft law' arrangements that find support among the entities representing partnered governmental-commercial sectors and actors. This 'soft law' recalibration is taking place in two distinct legal settings: international governmental organizations and on the level of nations' domestic regulatory legislation (Guzman \& Meyer, 2010).

\subsection{International governmental organizations (IGOS) and formation of international law}

To reiterate, we are looking at whether non-binding LTS Guidelines approved by the UNCOPUOS and by the UN General Assembly could become binding international law applicable to all states. According to Professor Stephan Hobe, Director of the University of Cologne's Institute of Air and Space Law, international governmental organizations (IGOs) facilitate the formation of binding international law by requiring member states to implement IGO policy through national regulatory legislation (Hobe, 2018). In this scenario, the non-binding LTS Guidelines could be approved by the UN General Assembly (UNGA) in a resolution that instructs states to implement the LTS Guidelines with national legislation. States then, would not be required to sign or ratify 'hard' law international agreements, but would instead signal their compliance with the non-binding UNGA resolutions through passage and implementation of national legislation. Such regulatory rules and agencies operating on the national level would ensure governmental or commercial entity compliance with international 'hard' and 'soft' agreements. This need not be limited to UNCOPUOS or UNGA resolutions ensuring sustainable outer space access and use. We would ask whether a similar scenario could be undertaken by other regional IGOs, such as the European Space Agency (ESA) or the European Union (EU), African Union (AU), Organization of American States (OAS), or other regional IGOs adopting guidelines for member implementation (Hobe, 2018).

\subsubsection{The Long-Term Sustainability Guidelines in UNCOPUOS}

A comprehensive article by the LTS Working Group Chair and Executive Director of the Secure World Foundation, Professor 
Peter Martinez, appearing in the February 2018 edition of Space Policy, details the process by which the UNCOPUOS approved 12 guidelines in 2016 (Martinez, 2018). At its June 2018 meeting, UNCOPUOS completed its consideration of the LTS Guidelines and formalized that approval in June 2019 (UNCOPUOS, 2019).

The Long-Term Sustainability (LTS) Guidelines adopted by the UNCOPUOS and considered by the United Nations General Assembly 4th Committee, represent the growing acknowledgement that the long-term sustainability of outer space access is endangered. The LTS Guidelines fall into four categories: (1) policy and regulatory framework for space activities, (2) safety of space operations, (3) international cooperation, capacity-building and (4) awareness and scientific and technical research and development (UNCOPUOS, 2018). The adopted Guidelines were those that already reflected widespread governmental and commercial practice, and as such, posed minimal regulatory overhead in terms of compliance or enforcement. The 2019 COPUOS Final Report specifies their legal status in Annex II:

\section{Status of the guidelines}

14. The existing United Nations treaties and principles on outer space provide the fundamental legal framework for the guidelines.

15. The guidelines are voluntary and not legally binding under international law, but any action taken towards their implementation should be consistent with the applicable principles and norms of international law. The guidelines are formulated in the spirit of enhancing the practice of States and international organizations in applying the relevant principles and norms of international law. Nothing in the guidelines should constitute a revision, qualification or reinterpretation of those principles and norms. Nothing in the guidelines should be interpreted as giving rise to any new legal obligation for States. Any international treaties referred to in the guidelines apply only to the States parties to those treaties.

Voluntary implementation of the guidelines

16. States and international intergovernmental organizations should voluntarily take measures, through their own national or other applicable mechanisms, to ensure that the guidelines are implemented to the greatest extent feasible and practicable, in accordance with their respective needs, conditions and capabilities, and with their existing obligations under applicable international law, including the provisions of applicable United Nations treaties and principles on outer space. States and international intergovernmental organizations are encouraged to administer existing and, if necessary, establish new procedures to meet requirements associated with the guidelines. In implementing these guidelines, States should be guided by the principle of cooperation and mutual assistance and should conduct all their activities in outer space with due regard for the corresponding interests of all other States [emphasis added]. (UNOOSA, 2019)

The next sections will suggest how the LTS Guidelines could pave the way for national legislative efforts to create what becomes, in effect, 'a general practice accepted as law'.

\section{National legislation as a source of international law}

While Professor Hobe's assertion, noted above, that a state's membership in an IGO (e.g. COPUOS or the ITU) may instigate an obligation for passage of national legislation implementing IGO policy, that legislation would apply only upon entities and activities directly under that state's regulatory jurisdiction as defined by that state's constitutive charter. Nonetheless, the UNCOPUOS adoption of the LTS Guidelines may be seen from the Hobe analysis also as an obligation to implement through national legislation. There are multiple examples of legislative and regulatory actions taken by states that either already comply with or were taken in compliance with the LTS Guidelines. (For example U.S. regulatory actions regarding space debris; Luxembourg and U.S. law respecting asteroid mining.) However, the question remains open whether national legislation could assume and exert a wider international applicability and/or jurisdiction. In other words, if states passed similar pieces of national legislation respecting an IGO obligation, could such legislation serve as evidence of a generalized state practice approaching the threshold of customary international law? What could serve as the legal nexus for making such an assertion? Let's look again at the ICJ Statute and how its sub-paragraph (c) may provide the bridge we are seeking:

1. The Court, whose function is to decide in accordance with international law such disputes as are submitted to it, shall apply:

A. international conventions, whether general or particular, establishing rules expressly recognized by the contesting states;

B. international custom, as evidence of a general practice accepted as law; C. the general principles of law recognized by civilized nations;

D. subject to the provisions of Article 59, judicial decisions and the teachings of the most highly qualified publicists of the various nations, as subsidiary means for the determination of rules of law.

In other words, as states use the LTS Guidelines as templates for national implementing legislation, could the Hobe approach (Hobe, 2018) be the first step towards recognition of a 'general principle of law'?

\subsection{Common elements of national legislation}

The second step may well be present in an intriguing interpretation of general principles operating as one of the sources of international law as analysed by Diane Howard, General Counsel to the USG's Office of Space Commerce (Howard, 2013). Howard argues that a general practice proximate of CIL can be derived if one assembles a set of general principles arising from in-depth comparisons of national legislation and regulations promulgated by states. Howard suggests that by comparing and assembling the common elements of those national laws and regulations pertaining to space activities one 'may distil a general principle of international law'. Although such national laws and regulations may be directed solely at national entities under the territorial and/or sovereign jurisdiction of the country's governmental entities, they could at the same time be considered both a 'general principle' as well as a 'general practice' of international law guiding judges' decisions as a source of law under the ICJ Statute.

In other words, a compendium of national laws addressing the regulation of space activities by entities under a state's jurisdiction might reveal amongst the diversity certain common themes, such as space debris mitigation and remediation, using the LTS Guidelines as a primary filter for establishing which themes already enjoy international recognition. In this way, national legislation itself would serve both as a general principle guiding such national legislation as well as a general practice of states accepted as law, i.e. CIL. CIL thus derived would not be limited by the actions of states on the international level, but would also encompass legislative and regulatory actions of states on a predominately national level of action and jurisdiction.

Indeed, the LTS Guidelines specifically recommend states take nation-level legislative and regulatory actions to supervise entities under their jurisdiction to ensure compliance with sustainability objectives. Capacity building, sharing of information, and 
recommendations to 'investigate and consider new measures' to manage space debris are among the agreed-upon 'rules of the road'. It is now incumbent on states to implement through adoption of national legislation.

\section{Closing observations}

This paper suggests how the LTS Guidelines, both approved and pending, are, even in their non-binding status, a significant achievement for identifying and guiding the national efforts of states to develop legislative and regulatory capacities addressing sustainability challenges in outer space. The key to mitigating the downward spiral towards a tragedy of the commons is to identify boundaries marking consensus about acceptable behaviour and raise transaction costs for those entities conducting activities falling outside. The endogenous challenges of space sustainability itself will require far-reaching responses. Using Hobe and Howard's regulation modelled after the LTS Guidelines and other efforts to promulgate 'rules of the road' such as the Group of Governmental Experts' Transparency and Confidence Building Measures, the EU Code of Conduct, the IADC Guidelines and ITU Radio Regulations (Martinez, 2018).

The LTS Guidelines will serve scholars and practitioners alike as a filter for their efforts to distil common themes among national legislative and regulatory practices. These may have the ability to coalesce as general principles that inform the formation of CIL establishing a higher transaction cost for non-compliance, promoting a more sustainable governance of outer space.

Acknowledgements. The analysis presented benefited greatly from guidance and insights provided by Professors Peter Martinez and Stephan Hobe, and U.S. Department of Commerce Counsel Diane Howard. All responsibility for the article's content and accuracy rest with this author alone.

Author contributions. This article's analysis was first developed in a co-authored conference paper, Unispace +60: Evolution of Long-Term Sustainability (LTS) Guidelines into Customary Legal Norms, presented at the 69th International Astronautical Federation Congress, 3 October 2018 in Bremen, Germany. The insightful contributions by conference paper co-authors Dr James H. Armstead and Dr Merve Erdem is gratefully acknowledged, with responsibility for the content and accuracy of this paper being mine alone.

Financial support. This research received no specific grant from any funding agency, commercial or not-for-profit sectors.

Conflict of interest. None.

Ethical standards. This article adheres to the Committee on Publication Ethics (COPE) guidelines on research and publications ethics.

\section{References}

Committee on Space Research (COSPAR) (2006). Rules to Prevent Biological Contamination on Planets and Other Celestial Bodies. Retrieved from https://en.wikipedia.org/wiki/Planetary_protection.

Guzman, A. \& Meyer, T. (2010). International soft law. Journal of Legal Analysis, 2(1), 171-225.

Hardin, G. (1968). The tragedy of the commons. Science, 162, 1243-1248.
Hobe, S. (2018). The role of intergovernmental organisations in the corpus iuris spatialis: from "declaring acceptance" to the advancement of international law. Presentation to Symposium on Intergovernmental Organizations and the Practice of Space Law, hosted by the European Space Policy Institute, Vienna, held on 21 June 2018. Retrieved from file:///Users/larryfmartinez/Dropbox/19\%20Projects\%20DB/19\%20Andreas \%20Losch\%20Project\%20DB/Program\%20ESPI-ESA\%20-\%20Space\%20Law \%20and\%20IGOs\%20-\%20joint\%20event\%20UNISPACE\%2050_14-62-18_ $\% 20$ i4.pdf.

Howard, D. (2013). Distilling general principles of international space law. Paper presented at Colloquium of the International Institute of Space Law, IAC-13, E7.5. Retrieved from https://www.elevenjournals.com/tijdschrift/ iisl/2013/5\%20Recent\%20Developments\%20in\%20Space\%20Law/IISL_2013_ 056_005_002.

International Telecommunication Union (ITU) (2010). Recommendation ITU-R S.1003-2 (12/2010), Environmental Protection of the Geostationary-Satellite Orbit. Retrieved from https://www.itu.int/dms_pubrec/itu-r/rec/s/R-REC-S. 1003-2-201012-I!!MSW-E.docx.

Malik, T. (2018). Elon Musk's Tesla roadster is headed to the asteroid belt. Space.com, 7 February 2018. Retrieved from https://www.space.com/39619spacex-falcon-heavy-roadster-to-asteroid-belt.html.

Martinez, L. (1985). Communications Satellites: Power Politics in Space. Artech House, Inc.

Martinez, L. (2011). Is there space for the UN in Bonn? Perspectives on the sustainability of outer space and cyberspace for UN organizations. In $\mathrm{N}$. S. Huerter \& S. Bruns (eds), Nachhaltig ins 21. Jahrhundert. 15 Jahre UNO Stadt Bonn. Bouvier Verlag.

Martinez, P. (2018). Development of an international compendium of guidelines for the long-term sustainability of outer space activities. Space Policy, 43, 2-5.

Salazar, D. E. (2019). India's Anti-Satellite Missile Test Is a Big Deal. Here's Why. Space.com. Retrieved from https://www.space.com/india-anti-satellitetest-significance.html.

Space Watch (2011). Schulte: Space is congested, contested, competitive. Space Watch. Retrieved from https://www.spacefoundation.org/news/schulte-spacecongested-contested-competitive.

United Nations (2018). Statute of the International Court of Justice, Article 38. Retrieved from http://www.icj-cij.org/en/statute.

United Nations Committee for the Peaceful Use of Outer Space (UNCOPUOS) (2018). Working Group on the Long-term Sustainability of Outer Space Activities: Preambular Text and Nine Guidelines. Conference room paper by the Chair of the Working Group on the Long-term Sustainability of Outer Space Activities. A/AC.105/C.1/2018/ CRP.18/Rev.1, 8 February 2018.

United Nations Committee for the Peaceful Use of Outer Space (UNCOPUOS) (2019). Report of the Committee on the Peaceful Uses of Outer Space, Sixty-second session (12-21 June 2019). A/74/20. Retrieved from https://www.unoosa.org/oosa/en/ourwork/copuos/2019/ index.html.

United Nations Office of Outer Space Affairs (UNOOSA) (1967). Treaty on Principles Governing the Activities of States in the Exploration and Use of Outer Space, including the Moon and other Celestial Bodies, 610 U.N.T.S. 205 ('Outer Space Treaty'). Retrieved from http://www.unoosa.org/pdf/publications/STSPACE11E.pdf.

United Nations Office of Outer Space Affairs (UNOOSA) (2019). Documents and resolutions. Retrieved from http://www.unoosa.org/oosa/documentsand-resolutions/search.jspx? \&view=resolutions.

Wikipedia. (2009). 2009 satellite collision. Retrieved from https:/en.wikipedia. org/wiki/2009_satellite_collision.

Williamson, O. (1996). The Mechanisms of Governance. Oxford University Press. 